How autonomy support mediates the relationship between self-efficacy and approaches to learning

Stefan Kulakow

University of Greifswald

\begin{abstract}
"This is an Accepted Manuscript of an article published by Taylor \& Francis in The Journal of Educational Research on 06/01/2020, available at http://wwww.tandfonline. com/10.1080/00220671.2019.1709402.”
\end{abstract}

Author Note

Stefan Kulakow, Department of Educational Science, Greifswald University. Correspondence concerning this article should be addressed to Stefan Kulakow, Department of Educational Science, Greifswald University, Ernst-Lohmeyer-Platz 3, 17489 Greifswald, Germany. Phone: 00493834 4203734, E-mail: stefan.kulakow@unigreifswald.de. 
AUTONOMY SUPPORT IN DIFFERENT LEARNING ENVIRONMENTS

Abstract

The significant interplay between self-efficacy, perceived autonomy support and approaches to learning in adolescent students is widely recognized. However, less is known about whether substantial differences exist between students from schools with different environments (student-centered vs. teacher-centered learning). To close this research gap, this study used latent mean comparison and multigroup multilevel mediation modelling with questionnaire data from a sample of German adolescent students $\left(N=1153 ; M_{\text {Age }} T 1=13.97\right.$, $\left.S D=1.37 ; M_{\text {Age }} T 2=14.27, S D=1.25\right)$ in two waves. Multigroup multilevel mediation modelling reveals that perceived autonomy support functions as a mediator in the association between self-efficacy and approaches to learning only for students from schools with a student-centered learning environment based on competency matrices in contrast to a teacherdirected learning environment. More specifically, adolescents' approaches to learning can be enhanced through autonomy-supportive learning independently of their self-efficacy.

Keywords: autonomy, student-centered learning, teacher-directed learning, approaches to learning, self-efficacy 
AUTONOMY SUPPORT IN DIFFERENT LEARNING ENVIRONMENTS

\section{How Autonomy Support Mediates the Relationship Between Self-Efficacy and}

\section{Approaches to Learning}

\section{Introduction}

Research has thoroughly documented the significant interplay between self-efficacy, autonomy, and approaches to learning (Baeten, Kyndt, Struyven, \& Dochy, 2010); in particular, self-efficacy directs learners toward a proactive autonomous role in their learning process (Bandura, 1997, 2013) and achievement (Schunk \& Pajares, 2005, 2009). However, research has also indicated that adolescence is a vulnerable time that is associated with a decline in students' self-efficacy (Bandura, 1997; Harter, 1996; Schunk, Meece, \& Pintrich, 2014; Schunk \& Pajares, 2002). Furthermore, in traditional teacher-directed learning (TDL), the proactive role that students are assumed to take is often compromised by external requirements such as consequent summative assessments and curricular expectations (Niemiec \& Ryan, 2009; Reeve \& Assor, 2011). It is therefore necessary to have learning environments that support students' proactive role through the enhancement of self-efficacy and autonomy to lead students to use beneficial approaches to learning such as control and elaboration.

Since theory indicates that the interplay of self-efficacy, autonomy support, and approaches to learning may depend on the learning environment (Kaplan \& Patrick, 2016; Meece, 1997; Schunk \& Pajares, 2002; Vansteenkiste, Simons, Lens, Sheldon, \& Deci, 2004; Yeager, Lee, \& Dahl, 2017), student-centered learning (SCL) environments are expected to overcome the detrimental effects of traditional TDL environments. Specifically, SCL environments based on competency matrices follow the recommendations made by selfefficacy and self-determination research (Bandura, 1997; Niemiec \& Ryan, 2009), which include the overall avoidance of lock-step sequences and the general provision of choice in the learning process. While such practices are also present in many TDL classrooms, these classrooms rely entirely on the teachers and, for instance, their application of autonomy- 


\section{AUTONOMY SUPPORT IN DIFFERENT LEARNING ENVIRONMENTS}

supportive behavior (Ryan \& Deci, 2016) and their provision of differentiated instruction, which is a major limitation on developing high self-efficacy (Schunk, 1995; Schunk \& DiBenedetto, 2016). Conversely, the SCL environment makes those rather necessary. However, empirical research on different learning environments is scant but highly necessary (Brackett \& Rivers, 2014; Hagenauer \& Hascher, 2011; Meyer, 2014). This is equally true for SCL environments (Krille, 2016; Saldern, 2011).

To closes this research gap, this study is intended to investigate whether educational contexts affect the interplay of self-efficacy, perceived autonomy support, and approaches to learning. In particular, perceived autonomy support is expected to function as a mediator only in educational contexts that enable autonomous decision-making. For this purpose, this study contrasts students from classes with a conventional TDL environment with those from classes with an SCL environment based on competency matrices.

\section{Self-Efficacy and Approaches to Learning}

Self-efficacy as theorized by Bandura refers to students' individual evaluation of their own capabilities to learn and perform expected behaviors (Bandura, 1997, 2013). In terms of learning processes in school, expected behavior can refer to the learning approach that students adopt (Baeten et al., 2010). These learning approaches relate to the students' intended use of strategies to approach certain tasks (Biggs, 2001; Entwistle, 1991; Marton \& Säljö, 1997). Using strategy to succeed in learning is a complex, dynamic process that involves cognitive, metacognitive, motivational, affective, and behavioral components (Weinstein, Acee, \& Jung, 2011; Weinstein et al., 2015).

The metacognitive component refers to the control of the learning process following a self-regulated approach, particularly evaluating one's own learning process in terms of monitoring and potential behavioral adaption (Bandura, 2013; Usher \& Schunk, 2018; Zimmerman \& Cleary, 2009; Zimmerman, Schunk, \& DiBenedetto, 2017). The cognitive domain relates to a taxonomy of processing information (Schwartz \& Goldstone, 2016; 


\section{AUTONOMY SUPPORT IN DIFFERENT LEARNING ENVIRONMENTS}

Weinstein et al., 2015). In that sense, memorization relates to surface-level approaches with the aim of rehearsal and reproduction of learning material and therefore builds the basis for deep understanding and competence development (Baeten et al., 2010). In turn, elaboration refers to these deep learning processes and intends to build upon previous knowledge and connect new content and skills with those that have already been learned. The intention of this approach is an understanding of content to foster application to new areas (Baeten et al., 2010).

Empirical evidence suggests that depending on the increasing levels of students' selfefficacy, they are more inclined to adopt a deep approach and less likely to choose a surfacelevel approach (Cassidy \& Eachus, 2000; Geitz, Brinke, \& Kirschner, 2016; Harris, 2003; Papinczak, 2009; Shen, Lee, Tsai, \& Chang, 2016) and prefer to control their own learning process (Bath \& Smith, 2009; Papinczak, 2009). These results become crucial due to a typical decline in students' self-efficacy during their time at school, especially with the onset of adolescence (Eccles \& Midgley, 1989; Eccles, Midgley, \& Adler, 1984; Harter, 1996; Schunk et al., 2014).

Particularly in schools, teachers and the accompanying learning environment play a crucial role in shaping this relationship. Student-centered learning environments have a tendency to encourage a deep approach, whereas TDL environments induce a surface-level approach to learning (Baeten et al., 2010).

\section{Autonomy Support as a Potential Mediator}

As stated in social cognitive theory (Bandura, 1989), students with high self-efficacy are inclined to be proactive and autonomous in their behavior and constantly strive to gain control of their own lives (Schunk \& DiBenedetto, 2016). In schools, the individual perception of autonomy depends on the provision of choice and freedom with regard to one's own study activities (Sierens, Vansteenkiste, Goossens, Soenens, \& Dochy, 2009). Empirical research has yielded proof of the association between self-efficacy and autonomy, although 


\section{AUTONOMY SUPPORT IN DIFFERENT LEARNING ENVIRONMENTS}

many researchers treat autonomy as an antecedent (Alivernini \& Lucidi, 2011; Garcia \& Pintrich, 1996) rather than a desirable outcome. Niemiec and Ryan (2009) have noted that the direction of this relation posits a distinctive difference between self-efficacy and selfdetermination theory. In this sense, the assumption is that the moment students experience self-efficacy, they need autonomy, and therefore autonomy support, in their learning processes in school.

However, summative evaluations and restrictions made due to imposed external goals, as are common in TDL environments, largely prevent autonomy in schools (Niemiec \& Ryan, 2009; Ryan \& Deci, 2017). This is particularly problematic because these increasingly restrictive TDL environments are established during a time when students constantly strive for more autonomy in their lives due to the onset of adolescence (Eccles \& Midgley, 1989; Eccles et al., 1993).

The provision of autonomy is an essential factor if schools want students to strive for a deep level of understanding (Mazlum, Cheraghi, \& Dasta, 2015; Reeve, Jang, Carrell, Jeon, \& Barch, 2004; Ryan \& Deci, 2000, 2017; Sierens et al., 2009). Although educators cannot convey an experience of autonomy, they must establish a framework in which autonomy is fostered. Studies have indicated that the support of autonomy fosters students' adoption of deep learning approaches such as elaboration, whereas a lack of autonomy induces surfacelevel approaches (Harris, 2003; Nijhuis, Segers, \& Gijselaers, 2008). Contrary to the common notion that autonomy support as a classroom climate variable depends on the class context (Marsh et al., 2012), multiple studies have demonstrated that only small proportions of autonomy support can be attributed to the classroom context (Diseth, Danielsen, \& Samdal, 2012; Diseth \& Samdal, 2014). Therefore, it seems that autonomy support is perceived quite differently among students.

Ryan and Deci (2000) have already promoted the idea that autonomy-supportive learning environments (e.g., SCL) play a crucial role in improving learning. However, there is 


\section{AUTONOMY SUPPORT IN DIFFERENT LEARNING ENVIRONMENTS}

not yet any research that has examined the interplay of self-efficacy, autonomy support, and approaches to learning in different learning contexts, namely traditional TDL and innovative SCL environments.

\section{Student-Centered Learning with Competency Matrices}

Instruction in SCL classrooms is centered on the work with competency matrices. These matrices are subject-specific and divide the skills and contents of a subject into distinctive competence areas (e.g., "dialogic speaking”) and respective competence levels (e.g., "I can understand the message of a conversation," "I can distinguish different types of conversations," "I can appropriately communicate depending on the addressee and the situation”) (Landesinstitut für Schulentwicklung, 2016). The resulting goal of a specific competence is thereby provided with descriptors such as "I can" statements. Certain competence levels are related to the educational standards established in Germany (Sekretariat der Ständigen Konferenz der Kultusminister der Länder in der Bundesrepublik Deutschland, 2004). Moreover, these levels lead the students to the material necessary to develop that respective competence completely independent of their teacher's input.

Before learning processes are initiated, the students' initial competence levels are evaluated through self- and external assessment. Thus, the initial individual position on a certain competence level is supposed to be the most adaptive to the students' previous knowledge. The individual proximal learning goals for each individual student may be determined with the help of these competency matrices. In turn, these matrices are supposed to enhance self-efficacy since the students' performances are continually and visibly reflected as progress in the matrices (Schunk, 1995; Schunk \& DiBenedetto, 2016).

Consequently, the autonomy in the learning process becomes one of the distinctive features of the SCL environment. The significance of autonomy for learning processes has prompted researchers to identify several behaviors of autonomy-supportive educators (Reeve, 2009; Reeve \& Halusic, 2009; Reeve \& Jang, 2006), such as patience to allow time for self- 


\section{AUTONOMY SUPPORT IN DIFFERENT LEARNING ENVIRONMENTS}

paced learning, the use of informational language in contrast to controlling language, the acceptance of students' negative affect, and generally adopting students' perspectives. Teachers are enabled to continually provide performance and attributional feedback to enhance students' self-efficacy (Bandura, 1997; DiBenedetto \& Schunk, 2018; Schunk, 1995; Usher \& Weidner, 2018). With regard to the use of learning strategies, the competency matrices moreover make competence-oriented goals transparent and enable a stepwise approach to them. It is apparent that early stages of competency development (e.g., memorization) are only a threshold for more cognitively demanding stages (e.g., elaboration).

\section{Current Study and Hypotheses}

This study aims to examine whether substantial differences exist in the interplay between self-efficacy, the perception of autonomy, and approaches to learning in students from SCL environments and students from TDL environments in terms of potential classroom effects.

In particular, the following hypotheses were tested based on the theoretical review: (H1) students differ in their perception of self-efficacy, perceived autonomy support, memorization, elaboration, and control. Specifically, it is assumed (H1a) that students from the SCL environment report higher self-efficacy because the competency matrices provide mastery experiences (Bandura, 1997). Moreover, it is expected (H1b) that students from SCL classrooms perceive higher autonomy support since SCL enables constant independent decision-making (Niemiec \& Ryan, 2009). Finally, it assumed (H1c) that students from SCL environments exhibit higher values of elaboration and control but lower values of memorization since SCL environments tend to induce deep approaches to learning (Baeten et al., 2010).

(H2) Perceived autonomy support may function as a mediator in the association between self-efficacy and approaches to learning (Baeten et al., 2010; Bandura, 1997; Ryan \& Deci, 2017); hence, potential learning environment (H2a) (Eccles \& Midgley, 1989; Ryan \& 


\section{AUTONOMY SUPPORT IN DIFFERENT LEARNING ENVIRONMENTS}

Deci, 2017) and classroom (H2b) (Eccles \& Midgley, 1989; Eccles et al., 1984; Eccles et al., 1993; Harter, 1996) differences are expected. Specifically, (H2a) perceived autonomy support is presumed to be a stronger mediator for students from schools with an SCL environment compared to students from schools with a TDL environment, because SCL better supports students' autonomy perception (Reeve, 2009; Reeve \& Halusic, 2009; Reeve \& Jang, 2006). Furthermore, $(\mathrm{H} 2 \mathrm{~b})$ since previous research has demonstrated that perceived autonomy support considerably varies between students (Diseth et al., 2012; Diseth \& Samdal, 2014), this interplay is assumed to be present on the student level rather than the classroom level.

\section{Method}

\section{Participants and Procedure}

The sample includes 1,153 students ages 12 to 18 years from grades 7 to $10\left(M_{\text {age }}=\right.$ 13.97; $S D=1.37,49 \%$ girls $)$ at Time $1(\mathrm{~T} 1)$ and $775\left(M_{\text {age }}=14.27, S D=1.25,49 \%\right.$ girls $)$ from the initial sample at Time 2 (T2) (0.5 years later) from six secondary schools in Germany in which all 57 classes were surveyed. Three of these schools were randomly selected from those schools that structure their learning environments based on SCL principles $\left(N_{\text {classes }}=36\right)$. This subsample includes 772 students $\left(M_{\text {age }}=13.85, S D=1.32,49 \%\right.$ girls) at T1. The other three schools were also randomly selected from those schools that structure their learning environments based on TDL principles $\left(N_{\text {classes }}=21\right)$. This subsample consists of 381 students $\left(M_{\text {age }}=14.22 ; S D=1.42 ; 52 \%\right.$ girls $)$ at T1. Socioeconomic status and parents' educational level could not be determined due to German privacy law restrictions that prohibit asking students for information about their parents. Likewise, ethnic background could not be determined due to small proportions of ethnic minorities, particularly in Mecklenburg-Vorpommern (4.3\%).

Students from both groups had only learned within their respective instructional design aside from some occasional changes of schools. Before approaching the students, we 


\section{AUTONOMY SUPPORT IN DIFFERENT LEARNING ENVIRONMENTS}

had to follow a strict procedure to comply with German privacy and educational laws as well as the Ethical Principles of Psychologists and Code of Conduct (American Psychological Association, 2002). First, we obtained permission from the Ministry of Education, Science and Culture of the federal state of Mecklenburg-Vorpommern, the Senate Administration for Education, Youth, and Family of the federal state of Berlin, the Ministry of Education and Science of the federal state of Schleswig-Holstein, and the Ministry of Schools and Education of the federal states of North Rhine-Westphalia. Second, we approached the schools with our study and informed them and the parents of the purpose of the data collection. After obtaining all necessary permission (from the schools, parents, and students), we conducted our study in the mid-winter term of 2015 (T1) and the mid-summer term of 2016 (T2). Two research assistants who were present throughout the process informed the students about the purpose of the study and its instruments, the voluntary nature of participation, and the anonymity of the data collection. These research assistants distributed the questionnaires to the students and explained the proper use of the Likert scales.

\section{Measures}

\section{Table 1}

Psychometric Quality of the Scales

\begin{tabular}{lccccc}
\hline & Nitems & \multicolumn{2}{c}{ Cronbach's Alpha $(\alpha)$} & \multicolumn{2}{c}{ congeneric reliability $(\omega)$} \\
& & SCL & TDL & SCL & TDL \\
\cline { 3 - 5 } self-efficacy & 10 & .84 & .85 & .85 & .85 \\
perceived & 5 & .80 & .78 & .81 & .79 \\
autonomy support & & & & & .77 \\
memorization & 4 & .74 & .78 & .77 & .76 \\
elaboration & 4 & .75 & .78 & .76 & .65 \\
control & 4 & .75 & .77 & .75 & \\
\hline
\end{tabular}


Independent variable: self-efficacy. For this measure, we utilized the German version of the general self-efficacy scale (Jerusalem \& Schwarzer, 1999). This scale consists of 10 items (e.g., "I can find a solution for every problem") with answers ranging from 1 ("not true") to 4 ("exactly true") on a four-point Likert-scale.

Mediator variable: perceived autonomy support. Perceived autonomy support was measured with a subscale of the "Support of Basic Needs Scales for Adolescent Students" (Müller \& Thomas, 2011). The subscale consists of five items (e.g., "My teacher likes it when I find my own way of problem solving”). Answers were rated on a four-point Likert scale ranging from 1 ("not true") to 4 ("exactly true").

Dependent variables: approaches to learning. Approaches to learning were assessed with three subscales from the German "Program for International Student Assessment" questionnaire regarding memorization strategies, elaboration strategies, and control strategies (Artelt, Baumert, Julius-McElvany, \& Peschar, 2004). The students were asked to rate the statements on a four-point Likert scale from 1 ("not true") to 4 ("exactly true"). Memorization was measured with four items (e.g., "When I study, I memorize all new material so that I can recite it"). Elaboration was also measured with four items (e.g., "When I study, I try to relate new material to things I have learned in other subjects"). The subscale control consists of five items (e.g., "When I study, I force myself to check to see if I remember what I have learned").

Covariates. Since previous research has suggested that approaches to learning may vary across student ages (Baumert, 1993), age was included as a covariate. Similarly, gender was included since prior studies have indicated that the interplay of the variables may differ between male and female students (Baeten et al., 2010).

\section{Statistical Analyses}

All analyses were conducted using Mplus 8.1 (Muthén \& Muthén, 1998-2012) via the robust maximum likelihood estimator (MLR). Since the data were hierarchical in nature (i.e., 


\section{AUTONOMY SUPPORT IN DIFFERENT LEARNING ENVIRONMENTS}

1,153 students/57 classes/6 schools), we used a multilevel approach (Hox, Moerbeek, \& Schoot, 2018; Raudenbush \& Bryk, 2002; Snijders \& Bosker, 2012).

Of the 1,153 cases used in the study, 392 (34\%) were affected by missing data. Across the 29 observed variables, missingness varied between $0.52 \%$ and $32.78 \%$. Full information maximum likelihood (FIML) estimation was used under the missing at random assumption (MAR; Rubin, 1987). Full information maximum likelihood estimation is a state-of-the-art technique for dealing with missing data (Schafer \& Graham, 2002) and is said to outperform multiple imputation in the multilevel context (Larsen, 2011).

We evaluated the fit of our models based on five primary fit indices as suggested by $\mathrm{Hu}$ and Bentler (1999): $\chi^{2}$ test of model fit, root mean square error of approximation (RMSEA) with its respective confidence intervals, standardized root mean square residual (SRMR), comparative fit index (CFI), and Tucker-Lewis index (TLI).

Initially, we performed a series of confirmatory factor analyses (CFAs) to establish measurement models and measurement invariance with the "type is complex approach" (Asparouhov, 2005). This way, measurement error can be explicitly modeled and separated from the latent constructs (Brown, 2015). The establishment of measurement invariance was compulsory for our research, because we had to ensure that the latent constructs remained invariant across both groups to test differences in the latent means (Hypothesis 1). Thus, we performed the CFA on all latent constructs and added constraints in a stepwise manner: first, all constructs were freely estimated for both groups individually (Model 1: configural measurement invariance). Second, both groups were merged (Model 2: factorial measurement invariance). Third, factor loadings were equated (Model 3: weak factorial measurement invariance). Finally, the factor intercepts were also equated (Model 4: strong factorial invariance). Reaching the level of strong factorial invariance was necessary to conduct latent mean comparisons between the two groups (Brown, 2015). The evaluations of measurement invariance were based on Chen's (2007) recommendations. Thus, for studies with $N>300$, 


\section{AUTONOMY SUPPORT IN DIFFERENT LEARNING ENVIRONMENTS}

weak factorial invariance is established if there are decreases in $\mathrm{CFI}<.010$, increases in RMSEA $<.015$, and increases in SRMR $<.030$. For strong factorial invariance, measurement invariance is established if there are decreases in CFI $<.010$, increases in RMSEA $<.015$, and increases in SRMR <.010.

Secondly, we conceptualized a multigroup, multilevel mediation model that examined the role of autonomy support on the student level (Preacher, Zyphur, \& Zhang, 2010), thereby controlling for potential classroom effects. Following Lüdtke, Marsh, Robitzsch, and Trautwein (2011), we used a manifest measurement/latent aggregation approach. For this approach, item scores were averaged for the L1 construct and then aggregated for the respective L2 construct, thereby correcting for sampling error. Lüdtke et al. (2011) have shown that such a partial correction approach may even outperform doubly latent models when there is only limited information about the L2 constructs (i.e., a small number of classes or a small number of individuals within classes).

At both levels, the mediation model (e.g., perceived autonomy support mediates the association between self-efficacy and approaches to learning) was specified. To evaluate the hypothesized differences in the interplay, two forms of the model were conceptualized: a less restricted model that freely estimated regression and covariance coefficients between all groups and a more restricted model assuming equated regression and covariance coefficients. The significance of the indirect effect was determined using symmetric confidence intervals (MacKinnon, 2008).

\section{Results}

\section{Descriptive Statistics and Intercorrelations}

Descriptive statistics (range, means, standard deviation, skewness, and kurtosis) as well as all intercorrelations between the variables of interest are presented in Table 1 separately for each subsample. 


\section{AUTONOMY SUPPORT IN DIFFERENT LEARNING ENVIRONMENTS}

\section{Table 2}

Intercorrelations between self-efficacy, autonomy (T1) and memorization, elaboration and control (T2) and their range, means, standard deviations, kurtosis and skewness for students following student-centered learning and teacher-directed learning separately

\begin{tabular}{|c|c|c|c|c|c|c|c|c|c|c|c|c|c|}
\hline & 2 & 3 & 4 & 5 & 6 & 7 & $\mathrm{M}$ & Range & SD & Skewness & Kurtosis & $\mathrm{ICC}(1)$ & $\operatorname{ICC}(2)$ \\
\hline \multicolumn{14}{|l|}{ Student-centered Learning } \\
\hline 1 self-efficacy $\mathrm{T} 1$ & $.42 * * *$ & $.14 * *$ & $.26^{* * *}$ & $28^{* * *}$ & -.08 & .08 & 2.74 & $1-4$ & 0.52 & $-.13(.09)$ & $.06(.18)$ & .05 & .54 \\
\hline 2 autonomy T1 & & $.23 * * *$ & $.25^{* * *}$ & $.35^{* * *}$ & $-.20^{* * *}$ & -.04 & 2.68 & $1-4$ & 0.67 & $-.21(.09)$ & $-.26(.18)$ & .07 & .60 \\
\hline 3 memorization $\mathrm{T} 2$ & & & $.39 * * *$ & $.56^{* * * *}$ & -.02 & -.06 & 2.57 & $1-4$ & 0.67 & $-.34(.11)$ & $-.09(.22)$ & .03 & .43 \\
\hline 4 elaboration T2 & & & & $.50^{* * * *}$ & -.06 & .04 & 2.54 & $1-4$ & 0.68 & $-.17(.11)$ & $-.14(.22)$ & .08 & .65 \\
\hline 5 control T2 & & & & & -.08 & $-.10^{*}$ & 2.86 & $1-4$ & 0.66 & $-.55(.11)$ & $.30(.22)$ & .06 & .56 \\
\hline 6 age & & & & & & .08 & 13.85 & $11-18$ & 1.32 & $.33(.09)$ & $-.71(.18)$ & & \\
\hline 7 gender $(0=$ girls, $1=$ boys $)$ & & & & & & & 0.51 & $0-1$ & .50 & $-.06(09)$ & $-2.00(.18)$ & & \\
\hline \multicolumn{14}{|l|}{ Teacher-directed Learning } \\
\hline 1 self-efficacy $\mathrm{T} 1$ & $.27 * * *$ & .13 & $.20^{* *}$ & .20 & .13 & $.20 * * *$ & 2.49 & $1-4$ & 0.50 & $.42(.13)$ & $.42(.25)$ & .08 & .61 \\
\hline 2 autonomy T1 & & $.15^{*}$ & .11 & $.27 * * *$ & -.09 & .03 & 2.38 & $1-4$ & 0.61 & $.17(.13)$ & $-.25(.25)$ & .16 & .78 \\
\hline 3 memorization $\mathrm{T} 2$ & & & $.17^{*}$ & $.60^{* * *}$ & .04 & -.12 & 2.83 & $1-4$ & 0.63 & $-.12(.15)$ & $-.28(.30)$ & .13 & .72 \\
\hline 4 elaboration T2 & & & & $.36^{* * *}$ & -.02 & .08 & 2.46 & $1-4$ & 0.61 & $.10(.15)$ & $-.11(.30)$ & .06 & .55 \\
\hline 5 control T2 & & & & & .01 & $-.14 * *$ & 2.83 & $1-4$ & 0.53 & $-.29(.15)$ & $.75(.30)$ & .04 & .40 \\
\hline 6 age & & & & & & .00 & 14.22 & $11-18$ & 1.42 & $.21(13)$ & $-.49(.25)$ & & \\
\hline 7 gender ( $0=$ girls, $1=$ boys $)$ & & & & & & & 0.48 & $0-1$ & 0.50 & $.06(.13)$ & $-2.01(.25)$ & & \\
\hline
\end{tabular}

Note. T1 $=$ Time $1 ; \mathrm{T} 2=$ Time $2{ }^{*} p<.05, * * p<.01, * * * p<.001$. 


\section{AUTONOMY SUPPORT IN DIFFERENT LEARNING ENVIRONMENTS}

\section{Confirmatory Factor Analyses: Latent Mean Comparison}

Before conducting a multigroup, multilevel mediation analysis, CFAs were performed to produce an initial measurement model and confirm measurement invariance across both groups. Strong factorial measurement invariance was reached (Chen, 2007). In sum, the measured constructs remained stable across both groups, allowing us to continue the investigation of the associations between the variables of interest with latent mean comparisons and multigroup, multilevel modeling.

\section{Table 3}

Model fit indices of the stepwise CFA procedure to proof measurement invariance

\begin{tabular}{lllllllllll}
\hline Model & $\mathrm{df}$ & $\chi^{2}$ & $p$ & CFI & RMSEA & $90 \%$ CI & SRMR & $\Delta$ CFI & $\Delta$ RMSEA & $\Delta$ SRMR \\
\hline Model 1a & 340 & 712.57 & $<.001$ & .930 & .038 & $.034-.042$ & .050 & & & \\
Model 1b & 340 & 519.12 & $<.001$ & .923 & .037 & $.013-.043$ & .063 & & & \\
Model 2 & 680 & 1231.33 & $<.001$ & .928 & .038 & $.034-.041$ & .055 & & & .002 \\
Model 3 & 703 & 1258.37 & $<.001$ & .928 & .037 & $.034-.040$ & .057 & .000 & -.001 & .001 \\
Model 4 & 726 & 1364.68 & $<.001$ & .917 & .039 & $.036-.042$ & .058 & -.011 & .002 & .001
\end{tabular}

Note. Model 1a-b = measurement model for SCL, TDL separately (configural invariance);

Model 2 = merged measurement model with all parameters free (form invariance); Model $3=$ equality of factor loadings (weak factorial invariance); Model 4 = equality of factor intercepts (strong factorial invariance).

Using the group of SCL students as a reference group, mean comparisons revealed that students in TDL environments reported significantly less self-efficacy at T1 $(\beta=-0.55, p$ $<.001)$ and perceived autonomy support at T1 $(\beta=-0.46, p<.001)$ but indicated higher memorization values at T2 $(\beta=0.51, p<.001)$. The latent means of elaboration at $\mathrm{T} 2(\beta=-$ $0.12, p=.32)$ and control at $\mathrm{T} 2(\beta=-0.01, p=.97)$ did not differ significantly. 


\section{AUTONOMY SUPPORT IN DIFFERENT LEARNING ENVIRONMENTS}

\section{Multigroup Multilevel Modeling}

The intercorrelations (see Table 1) already indicate that the interplay of the variables may vary across all groups. Consequently, we produced our hypothesized model in which perceived autonomy support mediates the association between self-efficacy and approaches to learning (i.e., memorization, elaboration, and control). First, a less restricted model that freely estimated regression and covariance coefficients was tested $\left(\chi^{2}(2)=3.395, p\left(\chi^{2}\right)=.18\right.$, CFI $\left.=.998, \mathrm{RMSEA}=.035, \mathrm{SRMR}_{\mathrm{within}}=.009, \mathrm{SRMR}_{\text {between }}=.011\right)$. Therefore, we included direct effects of self-efficacy on perceived autonomy support and on all three approaches to learning (i.e., memorization, elaboration, and control). We also added direct effects of perceived autonomy support on the approaches to learning. The approaches were allowed to covary. Second, a more restricted model was tested $\left(\chi^{2}(16)=42.671, \mathrm{p}\left(\chi^{2}\right)<.001, \mathrm{CFI}=.969\right.$, $\left.\mathrm{RMSEA}=.054, \mathrm{SRMR}_{\text {within }}=.015, \mathrm{SRMR}_{\text {between }}=.078\right)$, which additionally constrained the regression and covariance coefficients, implying no group differences. According to Chen (2007), the decreases in the fit indices $\left(\Delta \mathrm{CFI}=-.029, \Delta \mathrm{RMSEA}=.19, \Delta \mathrm{SRMR}_{\text {within }}=.006\right.$, $\Delta \mathrm{SRMR}_{\text {between }}=.067$ ) lead to a significant deterioration of model fit. Consequently, we accepted the less restricted model as our final model. In accordance with our hypotheses, this model implies that there are differences between the variables of interest patterns of the students in the two different learning environments.

Patterns for SCL. Table 3 presents the model results of the final model for the SCL group. Figure 1 depicts the central effects. 


\section{AUTONOMY SUPPORT IN DIFFERENT LEARNING ENVIRONMENTS}

\section{Table 4}

Results of the Multigroup Multilevel Analyses for Student-centered Learning

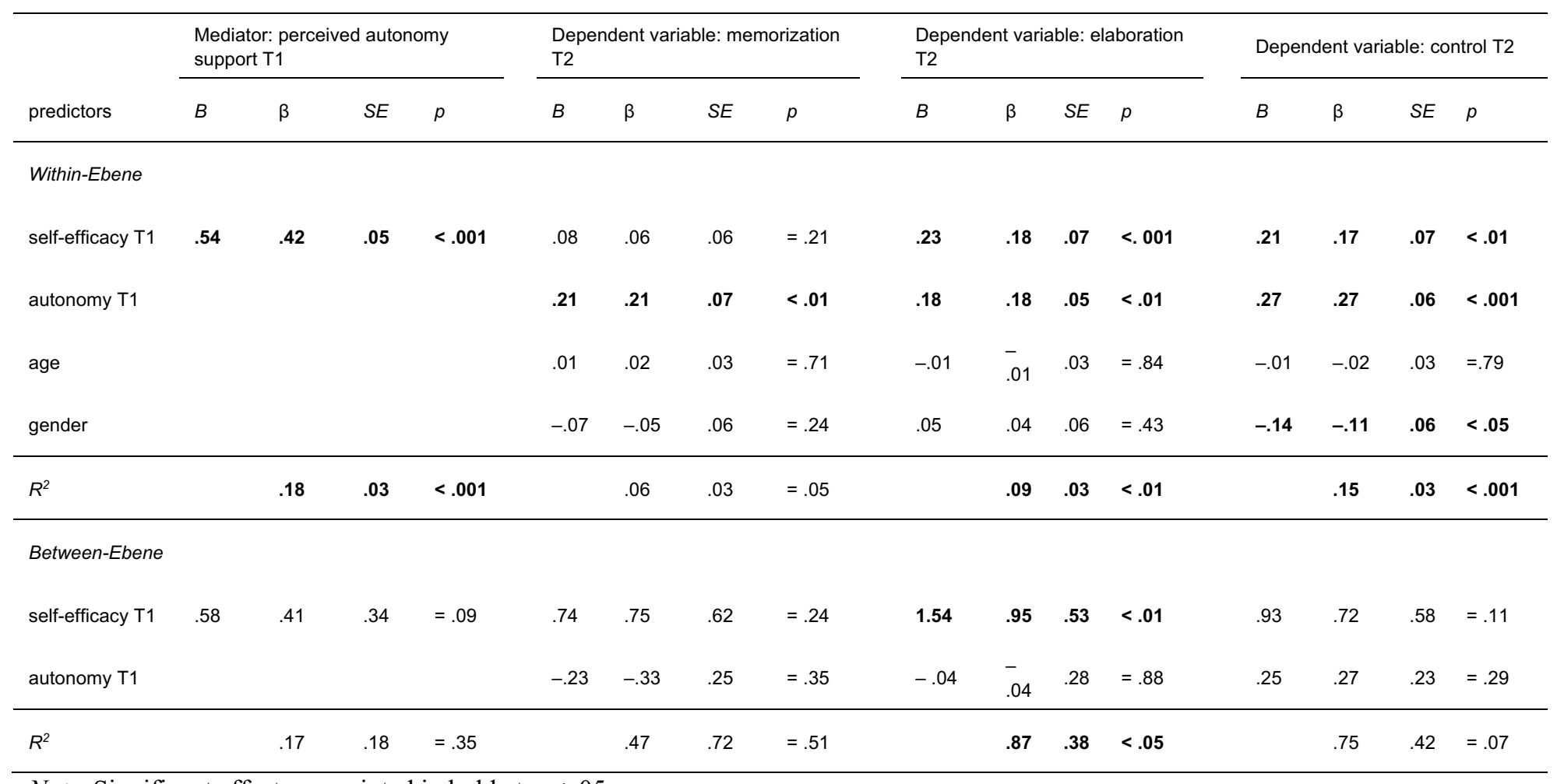

Note. Significant effects are printed in bold at $p<.05$. 


\section{AUTONOMY SUPPORT IN DIFFERENT LEARNING ENVIRONMENTS}

\section{Figure 1}

Final model for students following student-centered learning

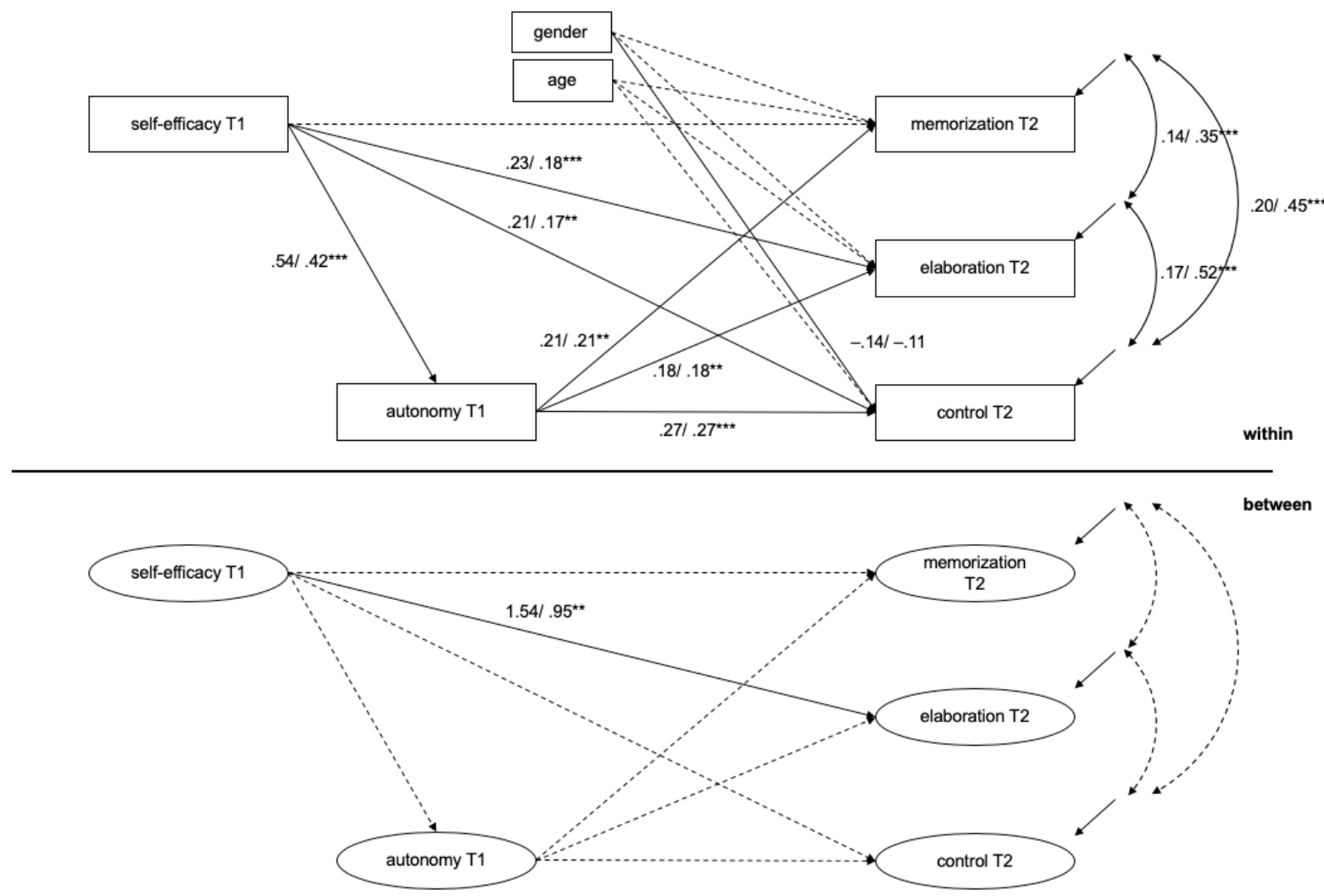

Note. Only significant estimates are displayed with unstandardized estimate first, and standardized estimate second; $* p<.05, * * p<.01, * * * p<.001$.

Direct effects. At the student level, students reported that self-efficacy was positively associated with perceived autonomy support at $\mathrm{T} 1(B=0.54, \beta=0.42, S E=0.05, p<.001)$, with elaboration at T2 $(B=0.23, \beta=0.18, S E=0.07, p<.001)$, and with control at T2 $(B=$ $0.21, \beta=0.17, S E=0.07, p<.01)$. Moreover, the perceived autonomy support at $\mathrm{T} 1$ reported by the students was associated with their reported memorization at T2 $(B=0.21, \beta=0.21, S E$ $=0.07, p<.01)$, elaboration at T2 $(B=0.18, \beta=.18, S E=.05, p<.01)$, and control at T2 $(B$ $=0.27, \beta=0.27, S E=0.06, p<.001)$. At the classroom level, only reported self-efficacy at $\mathrm{T} 1$ significantly predicted reported elaboration at $\mathrm{T} 2(B=1.54, \beta=0.95, S E=0.53, p<.01)$. 
AUTONOMY SUPPORT IN DIFFERENT LEARNING ENVIRONMENTS

Indirect effects. At the student level, all three indirect effects were significant in the SCL group. Perceived autonomy support fully mediated the association between reported selfefficacy at $\mathrm{T} 1$ and reported memorization at $\mathrm{T} 2(B=0.11, S E=0.04,95 \% C I[0.04-0.18])$. Furthermore, perceived autonomy support partially mediated the association between reported self-efficacy at $\mathrm{T} 1$ and reported elaboration at $\mathrm{T} 2(B=10, S E=0.03,95 \% C I[0.04-0.15])$ and between reported self-efficacy at T1 and reported control at T2 $(B=0.14, S E=0.03,95 \%$ $C I[0.08-0.21])$. No significant indirect effects were found on the classroom level.

Covariances. The residual covariances of memorization and elaboration were found to be positively associated $(r=.14, p<.001)$, as were the residual covariances of memorization and control $(r=.20, p<.001)$ and control and elaboration $(r=.17, p<.001)$. Moreover, gender was significantly associated with perceived autonomy support at T1 $(r=-.02, p<.05)$, and student age was significantly associated with perceived autonomy support at T1 $(r=-.02$, $p<.05)$.

Patterns for TDL. Table 4 presents the results of the final model for the TDL group. Figure 2 depicts the model's central effects. 


\section{AUTONOMY SUPPORT IN DIFFERENT LEARNING ENVIRONMENTS}

\section{Table 5}

Results of the Multigroup Multilevel Analyses for Teacher-directed Learning

\begin{tabular}{|c|c|c|c|c|c|c|c|c|c|c|c|c|c|c|c|c|}
\hline \multirow[b]{2}{*}{ predictors } & \multicolumn{4}{|c|}{$\begin{array}{l}\text { Mediator: } \\
\text { perceived autonomy support T1 }\end{array}$} & \multicolumn{4}{|c|}{$\begin{array}{l}\text { Dependent variable: } \\
\text { memorization T2 }\end{array}$} & \multicolumn{4}{|c|}{$\begin{array}{l}\text { Dependent variable: } \\
\text { elaboration T2 }\end{array}$} & \multicolumn{4}{|c|}{ Dependent variable: control T2 } \\
\hline & $B$ & $\beta$ & $S E$ & $p$ & $B$ & $\beta$ & $S E$ & $p$ & B & $\beta$ & $S E$ & $p$ & $B$ & $\beta$ & $S E$ & $p$ \\
\hline \multicolumn{17}{|l|}{ Within-Ebene } \\
\hline self-efficacy T1 & .32 & .27 & .07 & $<.001$ & .14 & .12 & .13 & $=.25$ & .23 & .19 & .09 & $<.01$ & .19 & .18 & .13 & $=.14$ \\
\hline autonomy T1 & & & & & .13 & .12 & .08 & $=.12$ & .06 & .06 & .07 & $=.40$ & .21 & .23 & .08 & $<.01$ \\
\hline age & & & & & .01 & .03 & .04 & $=.70$ & -.02 & -.04 & .04 & $=.69$ & .03 & .01 & .02 & $=.91$ \\
\hline gender & & & & & -.18 & -.15 & .08 & $<.05$ & .05 & .04 & .07 & $=.49$ & -.19 & -.18 & .05 & $<.001$ \\
\hline \multicolumn{17}{|l|}{$R^{2}$} \\
\hline \multicolumn{17}{|l|}{ Between-Ebene } \\
\hline self-efficacy T1 & 1.51 & .78 & .55 & $<.01$ & 2.28 & 1.28 & 1.34 & $=.09$ & 1.24 & .96 & 1.26 & $=.32$ & .69 & .90 & 1.06 & $=.51$ \\
\hline autonomy T1 & & & & & -.31 & -.82 & .52 & $=.56$ & -.31 & -.46 & .52 & $=.56$ & -.36 & -.91 & .49 & $=.47$ \\
\hline
\end{tabular}

Note. Significant effects are printed in bold at $p<.05$. 


\section{AUTONOMY SUPPORT IN DIFFERENT LEARNING ENVIRONMENTS}

\section{Figure 2}

Final model for students following teacher-directed learning

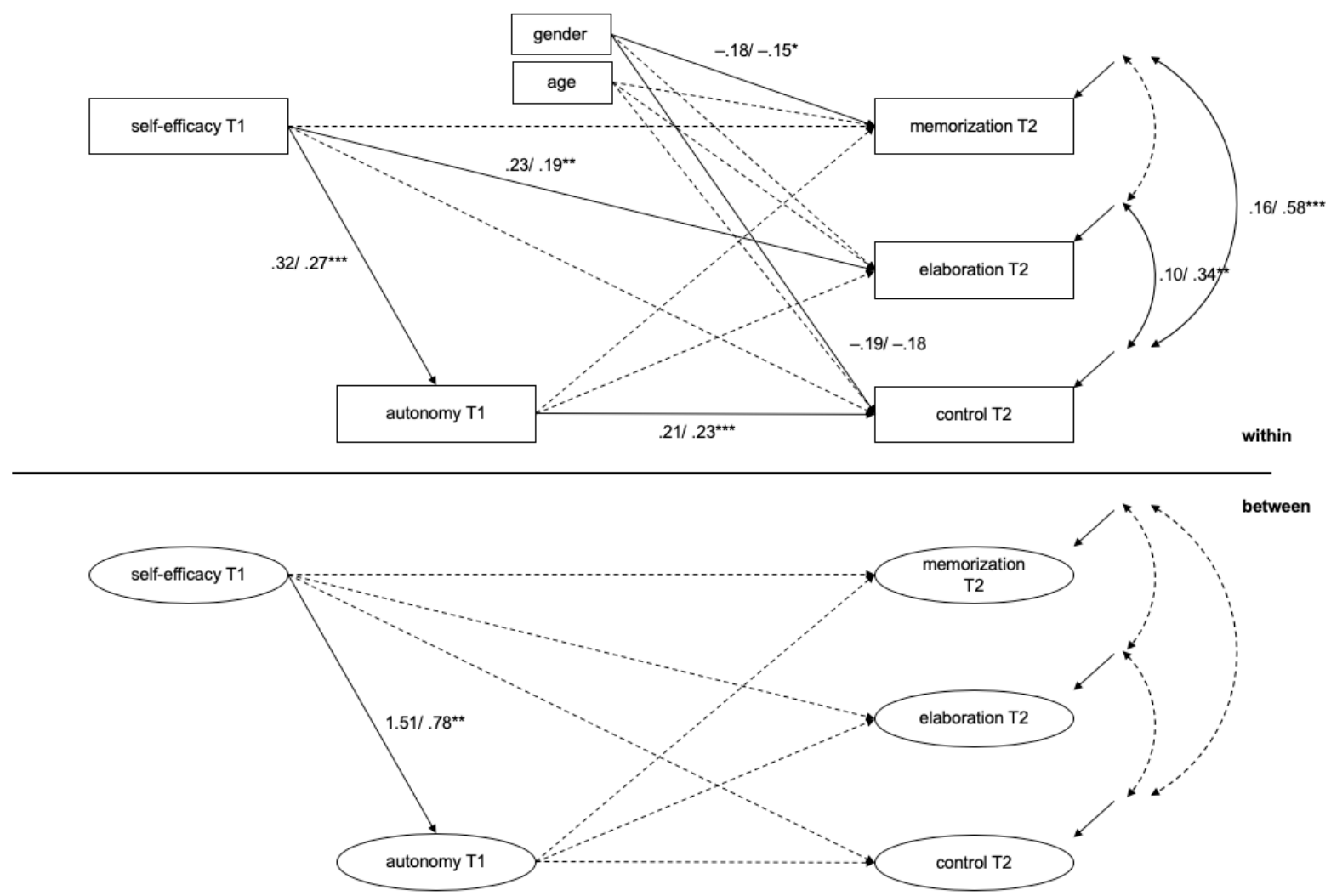

Note. Only significant estimates are displayed with unstandardized estimate first, and standardized estimate second ${ }^{*} p<.05, * * p<.01, * * * p<.001$.

Direct effects. At the student level, five effects were significant in the TDL group.

Reported self-efficacy at $\mathrm{T} 1$ positively predicted perceived autonomy support at $\mathrm{T} 1(B=0.32$, $\beta=0.27, S E=0.07, p<.001)$ and reported elaboration at T2 $(B=0.23, \beta=0.19, S E=.09, p$ $<.01)$. Moreover, perceived autonomy support at $\mathrm{T} 1$ predicted reported control at $\mathrm{T} 2(B=$ $0.21, \beta=0.23, S E=0.08, p<.01)$. Gender effects applied since gender negatively predicted reported memorization at $\mathrm{T} 2(B=-0.18, \beta=-0.15, S E=0.08, p<.05)$ and reported control at $\mathrm{T} 2(B=-0.19, \beta=-0.18, S E=.05, p<.001)$. 


\section{AUTONOMY SUPPORT IN DIFFERENT LEARNING ENVIRONMENTS}

Indirect effects. Contrary to the SCL group where all associations were mediated by perceived autonomy support at T1, in the TDL group, perceived autonomy support at T1 only mediated the association between reported self-efficacy at $\mathrm{T} 1$ and reported control at $\mathrm{T} 2(B=$ $0.07, S E=0.03,95 \% C I[0.02-0.12])$.

Covariances. In the TDL group, reported control was also associated with both reported memorization $(r=.16, p<.001)$ and reported elaboration $(r=.10, p<.01)$. Moreover, gender was associated with self-efficacy at T1 $(r=.05, p<.001)$, meaning that boys reported higher values of self-efficacy.

\section{Discussion}

The aim of this study was to clarify the substantial differences between adolescent students from classrooms with an SCL environment and students from classrooms with a TDL environment in terms of the interplay of self-efficacy, perceived autonomy support, and approaches to learning. Specifically, this study examined whether these two student groups differ in their mean values of these variables and whether perceived autonomy support functions as a mediator between self-efficacy and approaches to learning in the same manner for both groups considering potential classroom effects through a multilevel approach.

Hypothesis 1 was partly confirmed: with regard to Hypothesis 1a, reported selfefficacy was indeed significantly higher for students in SCL environments, which aligns with Bandura's (1997) posited sources of self-efficacy. The competency matrices orchestrate instruction to a large degree; hence, teachers are enabled to continually provide formative feedback and thereby use verbal persuasion. Moreover, mastery experiences are supposed to be the strongest source of self-efficacy. The continuous adaptation of individual competence level and the setting of new proximal learning goals allow for these experiences. Thus, the competency matrices follow Vygotsky’s zone of proximal development (Vygotsky, 1981).

Furthermore, as hypothesized in Hypothesis 1b, perceived autonomy support was lower for students in TDL classrooms, which aligns with recent school evaluations 


\section{AUTONOMY SUPPORT IN DIFFERENT LEARNING ENVIRONMENTS}

(Sächsisches Bildungsinstitut, 2013). Reeve and Halusic (2009) have suggested that allowing students to work at their own pace is a major determinant of autonomy support. In SCL, the respective tasks of competency matrices make this particularly easy, whereas a teacher instructing a class collectively will likely experience difficulty in coordinating instructional activities. Discussions abound regarding the restrictions that confront schools in terms of providing an autonomy-supportive environment (Niemiec \& Ryan, 2009). The SCL environment seems to circumvent some of these problems.

The students in TDL environments reported significantly more memorization than the students in SCL environments, which supports Hypothesis 1c; on the one hand, this result is aligned with the educational reports of various federal states in Germany (Institut für Qualitätsentwicklung, 2012; Sächsisches Bildungsinstitut, 2013), but on the other hand, it supports the idea that SCL environments induce fewer surface-level approaches (Baeten et al., 2010). This result could indicate a problem regarding the extent to which assessment is still based on memorization rather than elaboration (Morgan, 2016), but it could also denote a stronger focus on those approaches within instruction (Trigwell, Prosser, \& Waterhouse, 1999). However, both reasons question whether schools sufficiently address competence development as demanded by educational standards.

In contrast to Hypothesis 1c, students in SCL environments did not report higher values of elaboration and control. A possible explanation for this result might be the age of the participating students; for instance, Baumert (1993) has argued that students in early and middle adolescence do not have a very differentiated set of cognitive strategies and that these cognitive strategies continue to develop until late adolescence. An extensive body of research indicates a correlation of age and deep approaches to learning and a negative correlation between age and surface-level approaches to learning (Chamorro-Premuzic \& Furnham, 2009; Furnham, Christopher, Garwood, \& Neil Martin, 2007). Accordingly, future studies with older participants are warranted. With regard to control, the multilevel analysis revealed 


\section{AUTONOMY SUPPORT IN DIFFERENT LEARNING ENVIRONMENTS}

that boys tended to report lower values. This result is in line with the examination of gender differences by Duckworth and Seligman (2006) but contradicts more recent findings by Zimmerman and Kitsantas (2014), who have found no association between gender and metacognitive control strategies. Moreover, there were no significant associations between control and age. This result aligns with past research that found that general self-regulatory skills develop at the age of 10 (Smith, Borkowski, \& Whitman, 2008) and are henceforth subject to inter-individual differences rather than developmental differences (De Corte, Mason, Depaepe, \& Verschaffel, 2011).

Hypothesis 2 was also partly confirmed. In line with H2a, significant differences in the interplay between the self-efficacy, perceived autonomy support, and approaches of students from different learning environments (i.e., SCL vs. TDL) were identified. In the SCL environment, perceived autonomy support operated as a full mediator in the association between reported self-efficacy and reported memorization and as a partial mediator in the association between self-efficacy and reported control and between self-efficacy and reported elaboration. Since perceived autonomy support reduces the associations between self-efficacy and approaches to learning to zero (full mediation) or at least minimizes the effect (partial mediation), students with low levels of self-efficacy can be prevented from demonstrating fewer surface-level approaches, fewer deep approaches, and fewer metacognitive approaches in SCL environments through the perception of high levels of autonomy support. Thus, inclass autonomy support can protect students' approaches to learning independent of their selfefficacy. These results highly align with the theoretical foundation (Bandura, 1997; Ryan \& Deci, 2017) of self-determination theory, which posits that given the presence of more selfdetermined conditions, an internalization can be expected in which socially endorsed practices and ideals such as certain educational expectations are integrated into one's own value system (Deci \& Ryan, 1991; Ryan, Connell, \& Deci, 1985; Ryan \& Deci, 2017). In both SCL and TDL environments, students may not find many educational objectives interesting, and such 


\section{AUTONOMY SUPPORT IN DIFFERENT LEARNING ENVIRONMENTS}

educational objectives could be interpreted as a controlling factor. However, in SCL, students are offered incentives for internalizing a personal value of these objectives, such as more selfdetermined learning conditions paired with continuous depictions of the goals of students' learning tasks with "can-do" statements (Moeller, Theiler, \& Wu, 2012). Moreover, Sierens et al. (2009) have underscored that autonomy only develops its full potential if students perceive their educational setting as structured. The competency matrices provide such a continuous structure. In accordance with $\mathrm{H} 2 \mathrm{~b}$, classroom effects generally did not apply, meaning that the interplay of self-efficacy, perceived autonomy support, and approaches to learning are dependent on the individual rather than the classroom. However, at the class level, selfefficacy predicted elaboration, indicating that classes with high average self-efficacy result in higher average elaboration strategy use values.

By contrast, only one mediating effect could be determined for students in TDL environments. Specifically, perceived autonomy support mediated the association between self-efficacy and control. These results effectively coincide with the intercorrelations, which exhibit some significant but weak associations and predominantly non-significant associations. Similar effects have also been identified in studies that compared the associations between autonomy and achievement (Ng, Kenney-Benson, \& Pomerantz, 2004) and motivation (Lazarides \& Raufelder, 2017). A possible explanation for the lack of associations might lay in the nature of the classroom context (Lazarides \& Raufelder, 2017; Sierens et al., 2009). More specifically, Sierens et al. (2009) have suggested that at least moderate autonomy conditions have to be fulfilled to allow other perceived classroom variables such as perceived structure to have significant associations with approaches to learning. Patall, Sylvester, and Han (2014) have reported similar interaction effects. In this research context, this finding engenders the assumption that associations of perceived autonomy support can only be investigated if the proper contexts that allow for autonomy exist, making SCL environments preferable to TDL environments. In the TDL group, H2b 


\section{AUTONOMY SUPPORT IN DIFFERENT LEARNING ENVIRONMENTS}

was also confirmed. The interplay did not replicate at the classroom level, meaning that the interplay between self-efficacy, perceived autonomy support, and approaches to learning is determined by the individual student rather than his or her class.

\section{Practical Implications}

These results are promising since they indicate that structured autonomy-supportive learning environments can be established to foster deep learning approaches. Many schools still attempt to group students according to ability, because this method helps teachers satisfy their students' instructional needs (Chorzempa \& Graham, 2006). However, recent research has indicated that heterogeneity in classrooms can even be beneficial if students perceive a cognitively activating and supportive classroom climate (Decristan, Fauth, Kunter, Büttner, \& Klieme, 2017). The concept of teachers as facilitators is frequently the focus of discourses about student-centered environments (Goodyear \& Dudley, 2015; Hmelo-Silver \& Barrows, 2006; OECD, 2015). Nevertheless, the challenge for teachers is seemingly a desire to achieve the balance of reaching educational standards while simultaneously providing for a classroom climate that sufficiently addresses all of the learners' individual needs. Consequently, this scenario constantly requires instructional innovations (OECD, 2017), thus enabling the teachers to provide cognitive activation and a supportive classroom climate for individual students.

Student-centered learning environments with competency matrices apparently enable this approach in various ways. First, SCL primarily shifts the responsibility of the instruction to the students, which can develop their competences with the aid of the matrices. Therefore, the students' heterogeneity is acknowledged and adequately addressed. Additionally, teachers can focus on individual students, offer adequate formative feedback, and provide an adequately supportive classroom climate overall. 


\section{Strengths, Limitations, and Future Directions}

Although the current study offers important insights into how the relations of selfefficacy, perceived autonomy support, and approaches to learning differ between students from two learning environments, it is nonetheless subject to various limitations. First, this study exclusively utilized self-reported data. The use of questionnaires is regularly subject to uncertainty-related problems such as social desirability and common method variance

(Brannick, Chan, Conway, Lance, \& Spector, 2010). These problems are not exclusive to selfreported data (Chan, 2009; Spector, 2006), but it could certainly enrich the significance of our research to in future include additional measurements from external sources such as family members, teachers, and peers. Moreover, future studies should also include other student and classroom characteristics in addition to age and gender, such as socioeconomic status and teacher qualifications. Thereby, a more thorough analysis of employment of the classroom principles could be achieved to specifically see how consequent the teachers apply the SCL principles and which potentially alternative approaches of instruction teachers in TDL environments use. This kind of fidelity check would greatly improve the validity of the study and its inferences (Gitlin \& Parisi, 2016). After considering the advantages and disadvantages of using these self-reported measures, we decided to use them for the following reasons: (1) the focus of our research was the students' perception of the learning environment, and (2) adolescents were considered thoughtful enough to evaluate their internal states. Moreover, we tried to counteract potential bias by controlling for potential confounders. Second, our study only utilized two time points of measurement, which hindered the derivation of causal relations from our data and was additionally affected by a dropout rate of approximately $33 \%$. However, future studies could employ more waves to increasingly differentiate between various developmental timespans. This aspect especially accounts for the learning approaches of students in late adolescence (Baumert, 1993). Third, our study was not domain-specific in its evaluation of self-efficacy and approaches to learning. However, previous research 


\section{AUTONOMY SUPPORT IN DIFFERENT LEARNING ENVIRONMENTS}

(Baumert, 1993; Garner, 2016) has indicated that all constructs are potentially dependent upon and vary across certain domains. Thus, future studies should take different school subjects into account.

Despite these limitations, this study demonstrates some important strengths. First, hardly any studies have investigated the central antecedents of academic performance from the perspective of distinctive learning environments. Second, the complex statistical analyses were based on a large sample of adolescent students and allow for detailed analysis of the interplay of student perceptions in the classroom, which largely contributes to a general demand for innovative ideas in scholastic education (OECD, 2017). Third, the multilevel approach revealed that the interplay of self-efficacy, perceived autonomy support, and approaches to learning is an individual rather than classroom issue.

Additionally, future studies should focus more strongly on identifying the underlying mechanisms involved in individualized learning environments such as SCL. In particular, the underlying socio-motivational mechanisms and self-regulatory processes at hand should be of significant research interest because such research could better guide schools in shifting toward more autonomy-supportive learning environments. For example, Lazarides and Raufelder (2017) have emphasized the necessity of creating learning environments that enhance students' perception of motivational needs. Moreover, this prerequisite involves questions about how social comparison processes such as the "big fish, little pond" effect can be prevented if students learn under individualized and autonomous conditions (Hoferichter, Lätsch, Lazarides, \& Raufelder, 2018). Finally, future studies should include competence assessment to determine actual student performance. This approach could be especially beneficial for ensuring comparable achievement results across distinct learning environments. 
AUTONOMY SUPPORT IN DIFFERENT LEARNING ENVIRONMENTS

References

Alivernini, F., \& Lucidi, F. (2011). Relationship between social context, self-efficacy, motivation, academic achievement, and intention to drop out of high school: A longitudinal study. The Journal of Educational Research, 104(4), 241-252. doi:10.1080/00220671003728062

American Psychological Association. (2002). Ethical principles of psychologists and code of conduct. American Psychologist, 57(12), 1060-1073. doi:10.1037/0003066x.57.12.1060

Artelt, C., Baumert, J., Julius-McElvany, N., \& Peschar, J. (2004). Das lernen lernen: Voraussetzung für lebensbegleitendes lernen. Ergebnisse von pisa 2000 [Learners for life: Student approaches to learning. Results from PISA 2000]. Paris, France: OECD. Asparouhov, T. (2005). Sampling weights in latent variable modeling. Structural Equation Modeling: A Multidisciplinary Journal, 12(3), 411-434. doi:10.1207/s15328007sem1203_4

Baeten, M., Kyndt, E., Struyven, K., \& Dochy, F. (2010). Using student-centred learning environments to stimulate deep approaches to learning: Factors encouraging or discouraging their effectiveness. Educational Research Review, 5(3), 243-260. doi:10.1016/j.edurev.2010.06.001

Bandura, A. (1989). Human agency in social cognitive theory. American Psychologist, 44(9), 1175-1184. doi:10.1037/0003-066x.44.9.1175

Bandura, A. (1997). Self-efficacy: The exercise of control. New York, NY: Freeman. Bandura, A. (2013). The role of self-efficacy in goal-based motivation. In E. A. Locke \& G. P. Latham (Eds.), New development in goal setting and task performance (pp. 147157). New York, NY: Routledge. 


\section{AUTONOMY SUPPORT IN DIFFERENT LEARNING ENVIRONMENTS}

Bath, D. M., \& Smith, C. D. (2009). The relationship between epistemological beliefs and the propensity for lifelong learning. Studies in Continuing Education, 31(2), 173-189. doi:10.1080/01580370902927758

Baumert, J. (1993). Lernstrategien, motivationale orientierung und selbstwirksamkeitsüberzeugungen im kontext schulischen lernens [Learning strategies, motivational orientation and self-efficacy beliefs in the context of scholastic learning]. Unterrichtswissenschaft, 21(4), 327-354.

Biggs, J. B. (2001). Enhancing learning: A matter of style or approach? In R. J. Sternberg \& L. Zhang (Eds.), Perspectives on thinking, learning, and cognitive styles (pp. 73-102). Mahwah, NJ: Lawrence Erlbaum Associates.

Brackett, M. A., \& Rivers, S. E. (2014). Transforming students' lives with social and emotional learning. In R. Pekrun (Ed.), International handbook of emotions in education (pp. 368-388). New York, NY: Taylor \& Francis.

Brannick, M. T., Chan, D., Conway, J. M., Lance, C. E., \& Spector, P. E. (2010). What is method variance and how can we cope with it? A panel discussion. Organizational Research Methods, 13(3), 407-420. doi:10.1177/1094428109360993

Brown, T. A. (2015). Confirmatory factor analysis for applied research (2nd ed.). New York: Guilford Press.

Cassidy, S., \& Eachus, P. (2000). Learning style, academic belief systems, self-report student proficiency and academic achievement in higher education. Educational Psychology, 20(3), 307-322. doi:10.1080/713663740

Chamorro-Premuzic, T., \& Furnham, A. (2009). Mainly openness: The relationship between the big five personality traits and learning approaches. Learning and Individual Differences, 19(4), 524-529. doi:10.1016/j.lindif.2009.06.004

Chan, D. (2009). So why ask me? Are self-report data really that bad? In C. E. Lance \& R. J. Vandenberg (Eds.), Statistical and methodological myths and urban legends: 


\section{AUTONOMY SUPPORT IN DIFFERENT LEARNING ENVIRONMENTS}

Doctrine, verity and fable in the organizational and social sciences. (pp. 309-336). New York, NY: Routledge.

Chen, F. F. (2007). Sensitivity of goodness of fit indexes to lack of measurement invariance. Structural Equation Modeling: A Multidisciplinary Journal, 14(3), 464-504. doi:10.1080/10705510701301834

Chorzempa, B. F., \& Graham, S. (2006). Primary-grade teachers' use of within-class ability grouping in reading. Journal of Educational Psychology, 98(3), 529-541. doi:10.1037/0022-0663.98.3.529

De Corte, E., Mason, L., Depaepe, F., \& Verschaffel, L. (2011). Self-regulation of mathematics knowledge and skills. In B. J. Zimmerman \& D. H. Schunk (Eds.), Handbook of self-regulation of learning and performance (pp. 155-172). New York, NY: Taylor \& Francis.

Deci, E. L., \& Ryan, R. M. (1991). A motivational approach to self: Integration in personality. In R. Dienstbier (Ed.), Nebraska symposium on motivation: Perspectives on motivation (Vol. 38, pp. 237-288). Lincoln, NE: University of Nebraska Press.

Decristan, J., Fauth, B., Kunter, M., Büttner, G., \& Klieme, E. (2017). The interplay between class heterogeneity and teaching quality in primary school. International Journal of Educational Research, 86, 109-121. doi:10.1016/j.ijer.2017.09.004

DiBenedetto, M. K., \& Schunk, D. H. (2018). Self-efficacy in education revisited through a socialcultural lens. In G. A. D. Liem \& D. M. McInerney (Eds.), Big theories revisited 2 (pp. 117-139). Charlotte, NC: Information Age.

Diseth, Å., Danielsen, A. G., \& Samdal, O. (2012). A path analysis of basic need support, self-efficacy, achievement goals, life satisfaction and academic achievement level among secondary school students. Educational Psychology, 32(3), 335-354. doi:10.1080/01443410.2012.657159 


\section{AUTONOMY SUPPORT IN DIFFERENT LEARNING ENVIRONMENTS}

Diseth, A., \& Samdal, O. (2014). Autonomy support and achievement goals as predictors of perceived school performance and life satisfaction in the transition between lower and upper secondary school. Social Psychology of Education, 17(2), 269-291. doi:10.1007/s11218-013-9244-4

Duckworth, A. L., \& Seligman, M. E. P. (2006). Self-discipline gives girls the edge: Gender in self-discipline, grades, and achievement test scores. Journal of Educational Psychology, 98(1), 198-208. doi:10.1037/0022-0663.98.1.198

Eccles, J. S., \& Midgley, C. (1989). Stage-environment fit: Developmentally appropriate classrooms for young adolescents. In C. Ames \& R. Ames (Eds.), Research on motivation in education: Goals and cognitions (Vol. 3, pp. 139-186).

Eccles, J. S., Midgley, C., \& Adler, T. (1984). Grade-related changes in the school environment: Effects on achievement motivation. In J. G. Nicholls (Ed.), Advances in motivation and achievement: The development of achievement motivation (Vol. 3, pp. 283-331). Greenwich, CT: JAI Press.

Eccles, J. S., Midgley, C., Wigfield, A., Buchanan, C. M., Reuman, D., Flanagan, C., \& Iver, D. M. (1993). Development during adolescence: The impact of stage environment fit on young adolescents' experiences in schools and in families. American Psychologist, 48(2), 90-101. doi:10.1037/0003-066x.48.2.90

Entwistle, N. (1991). Approaches to learning and perceptions of the learning environment. Higher Education, 22(3), 201-204. doi:10.1007/bf00132287

Furnham, A., Christopher, A. N., Garwood, J., \& Neil Martin, G. (2007). Approaches to learning and the acquisition of general knowledge. Personality and Individual Differences, 43(6), 1563-1571. doi:10.1016/j.paid.2007.04.013

Garcia, T., \& Pintrich, P. R. (1996). The effects of autonomy on motivation and performancein the college classroom. Contemporary Educational Psychology, 21(4), 477-486. doi:10.1006/ceps.1996.0032 


\section{AUTONOMY SUPPORT IN DIFFERENT LEARNING ENVIRONMENTS}

Garner, R. (2016). When children and adults do not use learning strategies: Toward a theory of settings. Review of Educational Research, 60(4), 517-529. doi:10.3102/00346543060004517

Geitz, G., Brinke, D. J.-t., \& Kirschner, P. A. (2016). Changing learning behaviour: Selfefficacy and goal orientation in pbl groups in higher education. International Journal of Educational Research, 75, 146-158. doi:10.1016/j.ijer.2015.11.001

Gitlin, L. N., \& Parisi, J. M. (2016). Are treatment effects real? The role of fidelity. In L. N. Gitlin \& S. J. Czaja (Eds.), Behavioral intervention research: Designing, evaluating, and implementing (pp. 213-240). New York, NY: Springer.

Goodyear, V., \& Dudley, D. (2015). “I'm a facilitator of learning!” understanding what teachers and students do within student-centered physical education models. Quest, 67(3), 274-289. doi:10.1080/00336297.2015.1051236

Hagenauer, G., \& Hascher, T. (2011). Learning enjoyment in early adolescence. Educational Research and Evaluation, 16(6), 495-516. doi:10.1080/13803611.2010.550499

Harris, C. L. (2003). Understanding the role of epistemological beliefs in post-graduate studies: Motivation and conceptions of learning in first-year law students. The University of Texas at Austin. Retrieved from https://repositories.lib.utexas.edu/handle/2152/632

Harter, S. (1996). Teacher and classmate influences on scholastic motivation, self- esteem, and level of voice in adolescents. In J. Juvonen \& K. Wentzel (Eds.), Cambridge studies in social and emotional development - social motivation: Understanding children's school adjustment (pp. 11-42). New York, NY: Cambridge University Press.

Hmelo-Silver, C. E., \& Barrows, H. S. (2006). Goals and strategies of a problem-based learning facilitator. Interdisciplinary Journal of Problem-Based Learning, 1(1). doi:10.7771/1541-5015.1004 


\section{AUTONOMY SUPPORT IN DIFFERENT LEARNING ENVIRONMENTS}

Hoferichter, F., Lätsch, A., Lazarides, R., \& Raufelder, D. (2018). The big-fish-little-pond effect on the four facets of academic self-concept. Frontiers in Psychology, 9, 1247. doi:10.3389/fpsyg.2018.01247

Hox, J. J., Moerbeek, M., \& Schoot, R. v. d. (2018). Multilevel analysis: Techniques and applications (3rd ed.). New York, NY: Routledge.

Hu, L. T., \& Bentler, P. M. (1999). Cutoff criteria for fit indexes in covariance structure analysis: Conventional criteria versus new alternatives. Structural Equation Modeling: A Multidisciplinary Journal, 6(1), 1-55. doi:10.1080/10705519909540118

Institut für Qualitätsentwicklung (Ed.) (2012). Bilanzbericht der schulinspektion: Ergebnisse der externen evaluation an allen hessischen schulen [Report on the results of the school inspectorate: Results of the external evaluation at all schools in Hesse, Germany]. Wiesbaden, Germany: Institut für Qualitätsentwicklung.

Jerusalem, M., \& Schwarzer, R. (1999). Swe: Skala zur allgemeinen selbstwirksamtkeit [General self-efficacy scale]. In M. Jerusalem \& R. Schwarzer (Eds.), Skalen zur erfassung von lehrer- und schülermerkmalen: Dokumentation der psychometrischen verfahren im rahmen der wissenschaftlichen begleitung des modellversuchs selbstwirksame schulen. Berlin, Germany: Freie Universität Berlin.

Krille, F. (2016). Kompetenzraster als instrumente kompetenzorientierten, individualisierten und selbstgesteuerten unterrichts: Berufs- und wirtschaftspädagogische perspektiven zur entwicklung von kompetenzrastern [Competence matrices as an instrument for competence-oriented, individualized and self-regulated classroom]. Detmold, Germany: Eusl.

Landesinstitut für Schulentwicklung, (LIS). (2016). Lernprozesse sichtbar machen. Arbeiten mit kompetenzrastern und lernwegelisten Retrieved from http://www.schulebw.de/themen-und-impulse/individuelles-lernen-und-individuelle- 


\section{AUTONOMY SUPPORT IN DIFFERENT LEARNING ENVIRONMENTS}

foerderung/allgemein-bildende-schulen/kompetenzraster2016/deutsch/d_n152_0_basis.pdf

Larsen, R. (2011). Missing data imputation versus full information maximum likelihood with second-level dependencies. Structural Equation Modeling: A Multidisciplinary Journal, 18(4), 649-662. doi:10.1080/10705511.2011.607721

Lazarides, R., \& Raufelder, D. (2017). Longitudinal effects of student-perceived classroom support on motivation - a latent change model. Frontiers in Psychology, 8, 417. doi:10.3389/fpsyg.2017.00417

Lüdtke, O., Marsh, H. W., Robitzsch, A., \& Trautwein, U. (2011). A 2 x 2 taxonomy of multilevel latent contextual models: Accuracy-bias trade-offs in full and partial error correction models. Psychol Methods, 16(4), 444-467. doi:10.1037/a0024376

MacKinnon, D. P. (2008). Introduction to statistical mediation analysis. New York, NY: Lawrence Erlbaum Associates.

Marsh, H. W., Lüdtke, O., Nagengast, B., Trautwein, U., Morin, A. J. S., Abduljabbar, A. S., \& Köller, O. (2012). Classroom climate and contextual effects: Conceptual and methodological issues in the evaluation of group-level effects. Educational Psychologist, 47(2), 106-124. doi:10.1080/00461520.2012.670488

Marton, F., \& Säljö, R. (1997). Approaches to learning. In F. Marton, D. Hounsell, \& N. Entwistle (Eds.), The experience of learning. Implications for teaching and studying in higher education (2nd ed., pp. 39-58). Edinburgh, United Kingdom: Scottish Academic Press.

Mazlum, F., Cheraghi, F., \& Dasta, M. (2015). English teachers' self-efficacy beliefs and students learning approaches. International Journal of Educational Psychology, 4(3). doi:10.17583/ijep.2015.1137 


\section{AUTONOMY SUPPORT IN DIFFERENT LEARNING ENVIRONMENTS}

Meyer, D. K. (2014). Situating emotions in classroom practices. In R. Pekrun \& L. Linnenbrink-Garcia (Eds.), International handbook of emotions in education (pp. 458472). New York, NY: Routledge.

Moeller, A. J., Theiler, J. M., \& Wu, C. (2012). Goal setting and student achievement: A longitudinal study. The Modern Language Journal, 96(2), 153-169. doi:10.1111/j.1540-4781.2011.01231.x

Morgan, H. (2016). Relying on high-stakes standardized tests to evaluate schools and teachers: A bad idea. The Clearing House: A Journal of Educational Strategies, Issues and Ideas, 89(2), 67-72. doi:10.1080/00098655.2016.1156628

Müller, F. H., \& Thomas, A. E. (2011). Skalen zur wahrgenommenen basic needs unterstützung von schüler/innen [Support of basic needs scales for adolescent students]. Retrieved from Klagenfurt, Austria: https://ius.aau.at/wpcontent/uploads/2016/01/Schuelerfragebogen_BN_U.pdf

Muthén, L. K., \& Muthén, B. O. (1998-2012). Mplus user's guide (7th ed.). Los Angeles, CA: Muthén \& Muthén.

Ng, F. F., Kenney-Benson, G. A., \& Pomerantz, E. M. (2004). Children's achievement moderates the effects of mothers' use of control and autonomy support. Child Development, 75(3), 764-780. doi:10.1111/j.1467-8624.2004.00705.x

Niemiec, C. P., \& Ryan, R. M. (2009). Autonomy, competence, and relatedness in the classroom: Applying self-determination theory to educational practice. Theory and Research in Education, 7(2), 133-144. doi:10.1177/1477878509104318

Nijhuis, J., Segers, M., \& Gijselaers, W. (2008). The extent of variability in learning strategies and students' perceptions of the learning environment. Learning and Instruction, 18(2), 121-134. doi:10.1016/j.learninstruc.2007.01.009

OECD. (2015). Schooling redesigned: Towards innovative learning systems. Paris: OECD. 
AUTONOMY SUPPORT IN DIFFERENT LEARNING ENVIRONMENTS

OECD. (2017). The oecd handbook for innovative learning environments. Paris: OECD Publishing.

Papinczak, T. (2009). Are deep strategic learners better suited to pbl? A preliminary study. Advances in Health Sciences Education, 14(3), 337-353. doi:10.1007/s10459-008$9115-5$

Patall, E. A., Sylvester, B. J., \& Han, C.-w. (2014). The role of competence in the effects of choice on motivation. Journal of Experimental Social Psychology, 50, 27-44. doi:10.1016/j.jesp.2013.09.002

Preacher, K. J., Zyphur, M. J., \& Zhang, Z. (2010). A general multilevel sem framework for assessing multilevel mediation. Psychological Methods, 15(3), 209-233. doi:10.1037/a0020141

Raudenbush, S. W., \& Bryk, A. S. (2002). Hierarchical linear models: Applications and data analysis methods (2nd ed. Vol. 1). Thousand Oaks, CA: Sage.

Reeve, J. (2009). Why teachers adopt a controlling motivating style toward students and how they can become more autonomy supportive. Educational Psychologist, 44(3), 159175. doi:10.1080/00461520903028990

Reeve, J., \& Assor, A. (2011). Do social institutions necessarily suppress individuals' need for autonomy? The possibility of schools as autonomy-promoting contexts across the globe. In V. I. Chirkov, R. M. Ryan, \& K. M. Sheldon (Eds.), Human autonomy in cross-cultural context: Perspectives on the psychology of agency, freedom, and wellbeing (pp. 111-132). Heidelberg, Germany: Springer.

Reeve, J., \& Halusic, M. (2009). How k-12 teachers can put self-determination theory principles into practice. School Field, 7(2), 145-154. doi:10.1177/1477878509104319

Reeve, J., \& Jang, H. (2006). What teachers say and do to support students' autonomy during a learning activity. Journal of Educational Psychology, 98(1), 209-218. doi:10.1037/0022-0663.98.1.209 


\section{AUTONOMY SUPPORT IN DIFFERENT LEARNING ENVIRONMENTS}

Reeve, J., Jang, H., Carrell, D., Jeon, S., \& Barch, J. (2004). Enhancing students' engagement by increasing teachers' autonomy support. Motivation and Emotion, 28(2), 147-169. doi:10.1023/B:MOEM.0000032312.95499.6f

Rubin, D. B. (1987). Multiple imputation for nonresponse in surveys. New York, NY: Wiley.

Ryan, R. M., Connell, J. P., \& Deci, E. L. (1985). A motivational analysis of selfdetermination and self-regulation in education. In C. Ames \& R. E. Ames (Eds.), Research on motivation in education: The classroom milieu (pp. 13-51). Waltham, MA: Academic Press.

Ryan, R. M., \& Deci, E. L. (2000). Self-determination theory and the facilitation of intrinsic motivation, social development, and well-being. American Psychologist, 55(1), 68-78. doi:10.1037//0003-066x.55.1.68

Ryan, R. M., \& Deci, E. L. (2016). Facilitating and hindering motivation, learning, and wellbeing in schools: Research and observations from self-determination theory. In K. R. Wentzel \& D. B. Miele (Eds.), Handbook of motivation at schools (pp. 96-119). New York, NY: Routledge.

Ryan, R. M., \& Deci, E. L. (2017). Self-determination theory: Basic psychological needs in motivation, development, and wellness. New York, NY: Guilford.

Sächsisches Bildungsinstitut (Ed.) (2013). Externe schulevaluation in sachsen - 2. Ergebnisbericht [External school evaluation in Saxony — 2nd report]. Radebeul, Germany: Sächsisches Bildungsinstitut.

Saldern, M. v. (2011). Schulleistung 2.0: Von der note zum kompetenzraster [School achievement 2.0: From grades to competency matrices]. Norderstedt: Books on Demand.

Schafer, J. L., \& Graham, J. W. (2002). Missing data: Our view of the state of the art. Psychological Methods, 7(2), 147-177. doi:10.1037/1082-989x.7.2.147 


\section{AUTONOMY SUPPORT IN DIFFERENT LEARNING ENVIRONMENTS}

Schunk, D. H. (1995). Self-efficacy and education and instruction. In J. E. Maddux (Ed.), Self-efficacy, adaptation, and adjustment: Theory, research, and application (pp. 281303). New York, NY: Plenum Press.

Schunk, D. H., \& DiBenedetto, M. K. (2016). Self-efficacy theory in education. In K. R. Wentzel \& D. B. Miele (Eds.), Handbook of motivation at school (2nd ed., pp. 34-54). New York, NY: Routledge.

Schunk, D. H., Meece, J. L., \& Pintrich, P. R. (2014). Social cognitive theory. In D. H. Schunk, J. L. Meece, \& P. R. Pintrich (Eds.), Motivation in education: Theory, research and applications (pp. 139-194). Essex, United Kingdom: Pearson.

Schunk, D. H., \& Pajares, F. (2002). The development of academic self-efficacy. In A. Wigfield \& J. S. Eccles (Eds.), Development of achievement motivation (pp. 15-31). San Diego, CA: Academic Press.

Schunk, D. H., \& Pajares, F. (2005). Competence perceptions and academic functioning. In A. J. Elliot \& C. S. Dweck (Eds.), Handbook of competence and motivation (pp. 85104). New York, NY: Guilford Press.

Schunk, D. H., \& Pajares, F. (2009). Self-efficacy theory. In K. R. Wentzel \& A. Wigfield (Eds.), Handbook of motivation at school (pp. 35-53). New York, NY: Routledge.

Schwartz, D. L., \& Goldstone, R. (2016). Learning as coordination: Cognitive psychology and education. In L. Corno \& E. M. Anderman (Eds.), Handbook of educational psychology (3rd ed., pp. 61-75). New York, NY: Routledge.

Sekretariat der Ständigen Konferenz der Kultusminister der Länder in der Bundesrepublik Deutschland, (KMK). (2004). Bildungsstandards im fach deutsch für den mittleren schulabschluss - beschluss vom 4.12.2003 [Educational standards in German for the Mittlere Reife certification]. Munich, Germany: Wolters Kluwer.

Shen, K.-M., Lee, M.-H., Tsai, C.-C., \& Chang, C.-Y. (2016). Undergraduate students' earth science learning: Relationships among conceptions, approaches, and learning self- 


\section{AUTONOMY SUPPORT IN DIFFERENT LEARNING ENVIRONMENTS}

efficacy in taiwan. International Journal of Science Education, 38(9), 1527-1547. doi:10.1080/09500693.2016.1198060

Sierens, E., Vansteenkiste, M., Goossens, L., Soenens, B., \& Dochy, F. (2009). The synergistic relationship of perceived autonomy support and structure in the prediction of self-regulated learning. British Journal Educational Psychology, 79(1), 57-68. doi:10.1348/000709908X304398

Smith, L. E., Borkowski, J. G., \& Whitman, T. L. (2008). From reading readiness to reading competence: The role of self-regulation in at-risk children. Scientific Studies of Reading, 12(2), 131-152. doi:10.1080/10888430801917167

Snijders, T. A. B., \& Bosker, R. J. (2012). Multilevel analysis: An introduction to basic and advanced multilevel modeling (2nd ed.). Los Angeles, CA: Sage.

Spector, P. E. (2006). Method variance in organizational research: Truth or urban legend? Organizational Research Methods, 9(2), 221-232. doi:10.1177/1094428105284955

Trigwell, K., Prosser, M., \& Waterhouse, F. (1999). Relations between teachers' approaches to teaching and students' approaches to learning. Higher Education, 37(1).

Usher, E. L., \& Schunk, D. H. (2018). Social cognitive theoretical perspective of selfregulation. In D. H. Schunk \& J. A. Greene (Eds.), Handbook of self-regulation of learning and performance (2nd ed., pp. 19-35). New York, NY: Routledge.

Usher, E. L., \& Weidner, B. L. (2018). Sociocultural influences on self-efficacy development. In A. D. Liem \& D. M. McInerney (Eds.), Big theories revisited 2 (pp. 141-164). Charlotte, NC: Information Age.

Vygotsky, L. S. (1981). Mind in society. The development of higher psychological processes. Cambridge, MA: Harvard University Press.

Weinstein, C. E., Acee, T. W., \& Jung, J. (2011). Self-regulation and learning strategies. New Directions for Teaching and Learning, 2011(126), 45-53. doi:10.1002/t1.443 


\section{AUTONOMY SUPPORT IN DIFFERENT LEARNING ENVIRONMENTS}

Weinstein, C. E., Krause, J. M., Stano, N., Acee, T. W., Jaimie, M. K., \& Nancy, S. (2015). Learning to learn International encyclopedia of the social \& behavioral sciences (pp. 712-719)

Zimmerman, B. J., \& Cleary, T. J. (2009). Motives to self-regulate learning: A social cognitive account. In K. R. Wentzel \& A. Wigfield (Eds.), Handbook of motivation at school (pp. 247-264). New York, NY: Routledge.

Zimmerman, B. J., \& Kitsantas, A. (2014). Comparing students' self-discipline and selfregulation measures and their prediction of academic achievement. Contemporary Educational Psychology, 39(2), 145-155. doi:10.1016/j.cedpsych.2014.03.004

Zimmerman, B. J., Schunk, D. H., \& DiBenedetto, M. K. (2017). The role of self-efficacy and related beliefs in self-regulation of learning and performance. In A. j. Elliot, C. S.

Dweck, \& D. S. Yeager (Eds.), Handbook of competence and motivation: Theory and application (2nd ed., pp. 313-333). New York, NY: Routledge. 